\title{
SYMBOLIC INTERACTIONISM AND CAREER OUTSIDER: A THEORETICAL PERSPECTIVE FOR CAREER STUDY ${ }^{1}$
}

\author{
Leandro Eduardo Vieira Barros ${ }^{2}$ \\ Mônica Carvalho Alves Cappelle ${ }^{3}$ \\ Paula Guerra $^{4}$
}

http://dx.doi.org/10.1590/1413-2311.231.86969

\begin{abstract}
In this article we present a theoretical and methodological discussion for the study of career in the perspective of symbolic interactionism. A possible approach in this scope leads us to what can be termed as an outsider career. The outsider career consists of a concept developed by Becker $^{1}$ (2008), from which the individual is considered by the other members of society an "outsider" person for having an unconventional behavior. In this way, this approach to career study considers the individual's social context, their interactions, their characteristics and the process of labeling. The use of symbolic interactionism for the analysis of the outsider career implies their own theoretical and methodological perspective, opening up possibilities for new research with an interdisciplinary look, focused on the social context, considering all the social actors involved in the outsider career.
\end{abstract}

Keywords: Outside career. Symbolic interactionism. Research Perspective.

\footnotetext{
${ }^{1}$ Recebido em 19/10/2018; aprovado em 20/12/2018.

${ }^{2}$ Instituto Federal de Educação, Ciência e Tecnologia do Sudeste de Minas Gerais, São João del -Rei - MG (Brasil) - leandro.barros@ifsudestemg.edu.br

${ }^{3}$ Universidade Federal de Labras, Lavras - MG (Brasil) - edmo@,dae.ufla.br

${ }^{4}$ Universidade do Porto, Faculdade de Letras, Porto (Portugal) - mariadeguerra@gmail.com
} 


\title{
INTERACIONISMO SIMBÓLICO E CARREIRA OUTSIDER: UMA PERSPECTIVA TEÓRICA PARA O ESTUDO DE CARREIRA
}

\begin{abstract}
RESUMO
Neste artigo se apresenta uma discussão teórica e metodológica para o estudo de carreira na perspectiva do interacionismo simbólico. Uma possível abordagem neste âmbito conduz-nos ao que pode designar-se por carreira outsider. A carreira outsider consiste em um conceito desenvolvido por Becker (2008), a partir do qual o indivíduo é considerado pelos demais membros da sociedade um outsider - uma pessoa "de fora" - por ter um comportamento não convencional. Desta forma, essa abordagem para o estudo de carreira considera o contexto social do indivíduo, suas interações, suas características e o processo de rotulação. O recurso ao interacionismo simbólico para a análise da carreira outsider nos implica numa perspectiva teórica e metodológica próprias, nos abrindo possibilidades de novas pesquisas com um olhar interdisciplinar, voltadas para o contexto social, considerando todos os atores sociais envolvidos na carreira outsider.
\end{abstract}

Palavras-chave: Carreira outsider. Interacionismo simbólico. Perspectiva de pesquisa.

\section{INTERACCIONISMO SIMBÓLICO Y CARRERA OUTSIDER: UNA PERSPECTIVA TEÓRICA PARA EL ESTUDIO DE LA CARRERA}

\begin{abstract}
RESUMEN
En este artículo se presenta una discusión teórica y metodológica para el estudio de la carrera en la perspectiva del interaccionismo simbólico. Un posible abordaje en este ámbito nos conduce al concepto de carrera outsider. La carrera outsider consiste en un concepto desarrollado por Becker (2008), a partir del cual el individuo es considerado por los demás miembros de la sociedad como un outsider - una persona "de afuera" - por tener un comportamiento no convencional. De esta forma, ese abordaje para el estudio de carrera considera el contexto social del individuo, sus interacciones, sus características y el proceso de rotulación. El recurso al interaccionismo simbólico para el análisis de la carrera outsider nos coloca en una perspectiva teórica y metodológica propias, abriéndonos la posibilidad de
\end{abstract}


nuevas investigaciones con una mirada interdisciplinar, direccionadas para el contexto social, considerando todos los actores sociales envueltos en la carrera outsider.

Palabras clave: Carrera outsider. Interaccionismo simbólico. Perspectiva de investigación

\section{INTRODUCTION}

The concept of career has a wide diversity of definitions. Thus, there is a diversity of meanings about career, namely: salaried employment or unpaid activity; belonging to a professional group (unionized or not) or the manifestation of the purest idiosyncrasy (the career of an artist); vocation or occupation; position in an organization (associated with passages by various positions in the institutional hierarchy) or trajectory of an individual who works; or a personal script for the realization of the individual's own desires (BENDASSOLLI, 2009).

According to Adamson, Doherty and Viney (1998), career is not simply a job, but something that understands the notion of development and the logic of progress. In this way, Carvalho (2007) emphasizes that the occupation or profession only becomes a career when incorporating the context of temporality. Career makes use of the temporal condition (continuity in time), while the profession demands the formation, status and institutionalization of an occupation. Therefore, the career encompasses profession, vocation and work, which, over time, gain a conceptual border.

In the contemporary context, the career is in evidence in different areas of knowledge (administration, psychology, sociology), which enablesan interdisciplinary discussion. However, many studies focus on the professional path and the segregation between individual and organization, which characterizes the lack of innovation when studying the subject (CLOSS; ROCHA-DE-OLIVEIRA, 2015; DELUCA, ROCHA-DE-OLIVEIRA; CHIESA, 2016). Mainly because of the lack of studies that address the subjective dimension of the career, that is, the life of the worker subject (HUGLES, 1937).

Regardin the interdisciplinary approach, Khapova and Artur (2011) emphasize the importance of this aspect for the career study, in order to contemplate different areas of knowledge (psychology, social psychology, economics, administration, and sociology). Symbolic interactionism lies between social psychology and sociology. According to Mendonça (2002), it's a theoretical and methodological approach that may be used in 
management studies. The interactionist perspective frames what can be called Howard S. Becker's Labeling Theory, in which the individual or group is considered deviant by other members of society. The concept of outsider ${ }^{2}$ appears, in this way, in 1963, in the ambit of the sociology of the deviation, through the theory of the labeling, developed by Becker with the publication of the book "Outsiders: studies in the sociology of deviance".

Becker (2008) highlights the social interaction of the individual with the workplace, family, friends, society and clients/audience, and the individual's interaction with the social context throughout the career development. Hughes (1937) proposed the relevance of the subjective career dimension. In introducing the subjective conception to understand career in the interactionist perspective -, when treating the individual and its social interaction through the meanings and interpretations of the actions that occur in the social context, Hughes innovated in the scope of the approaches on the development of career.

In view of the importance of the interdisciplinary approach to career study, this work will focus on the areas of knowledge of sociology and administration. Using the theory of the labeling to understand careers considered outsiders, as proposed by Becker (2008), is using a theory of sociology to understand the career in the context of administration.

Thus, it can be shown that the labeling process of the outsider career can have social, professional and psychological implications (ELIAS; SCOTSON, 2000). The social implications deal with non-belonging to social groups cosidered normal; the professional implications refer to the fact that a carrer is not seen as prestigious, lack of status and financial issues; the psychological implications refer to family and friends pressure (OLIVEIRA, 2011; DUARTE; SILVA, 2013), on the other hand, it is perceived from prejudices, being considered marginalized (BECKER, 2008).

Different careers are labeled as outsiders: visual artists, artisans, actors, musicians, traditional and popular dancers, circus artists, models, athletes, astrologers and numerologists, esotericists and sex workers. These careers are labeled by institutions as (Ministry of Labor and Employment, Brazilian Institute of Geography and Statistics, National Industrial Apprenticeship Service), among others, and by workers when recognizing their characteristics and identifying with them (BARROS; CAPPELLE; SOUZA; LOBATO, 2016). In this scenario, Becker (2008) emphasizes that it is important to study these careers, since it is an opportunity to give voice to outsiders, in a context in which, often, their opinions are despised under the perspective of symbolic interactionism.

As the general objective of this article is to present a theoretical and methodological discussion for the study of career in the perspective of symbolic interactionism - presenting a 
sociological, theoretical and methodological perspective -, it is intended to contribute to a better understanding of the theme and provide contributions to scholars in the area.

What contributes greatly to the relevance of this study is the fact that in it is introduced the sociological perspective in the study of the career. Greater relevance is found in privileging the sociology of the deviation for analysis of the outsider career in the context of the administration. According to Centurião (2003), the deviant behavior cannot be explained by a single theory or single approach; it must be done in an interdisciplinary way. In this scenario, Becker (2008) points out that the deviation field is a living terrain and capable of generating interesting research ideas about: Who labels whom? What do they label? Moreover, in what circumstances is the labeling successful or not? (BECKER, 1977). Therefore, when studying outsider behavior, it is convenient to understand who imposes the rules or develops the accusations by identifying an individual or group as an outsider (HERPIN, 1982; LIMA, 2001; MISKOLCI, 2005; BECKER 2008).

In this particular study, interactionist sociological thinking can bring contributions on the understanding of the outsider career and its labeling process (VELHO, 1985). Effectively Carvalho, Borges and Rêgo (2010) highlight the evolution of the interactionist thought and its theoretical possibilities of study of social life, and Mendonça (2002) highlights the possibility of filling a gap in the administration literature when conducting research in the area. In addition, it was verified that there are no works developed in Brazil that contemplate the issue of outsider careers.

This article is organized in four sections. The first section seeks to discuss the concepts of career and outsider career as well as present the theory of the labeling. The next section seeks to frame the outsider career in the interactionist perspective. The third section will demonstrate the approximation of the themes. Finally, some final considerations are described.

\section{CAREER AND OUTSIDER CAREER}

Different theoretical fields have contributed to career problems and their own understanding. The sociology of professions contributes through the individual, social and institutional dimensions. The individual dimension comprises the construction and experience of the individual at work; the social dimension involves the division and organization of work and the institutional dimension is demarcated by the process of social actors in the defense of their interests against the State. The contribution of psychology of work involves the concepts 
of psychic life, identity, self, development and growth of the person and subjectivity. The contribution of the administration is in the understanding of the career in function of its conceptual development. Another contribution is the double vision, individual and organization. At the organizational level the career is in structure and routines, at the individual level refers to the subjective and career strategies (BENDASSOLLI, 2009).

According to Adamson, Doherty and Viney (1998), the meaning of career may have different understandings depending on the social context in which it is embedded. In everyday conception, people talking about career understand that they are dealing with their work career, referring to what they do in life and whom they work for. From the organizational perspective, it represents benefits in the conceptual and practical context. It is a management plan across organizational levels, noting the cultural and philosophical characteristics to develop the individual's talent within the organization. For the worker, it may have different meanings, such as accomplishing economic needs, social and symbolic status (dream of life). In the economic context, the career has been seen as a human capital that is added education and experience throughout life. In addition, for the political sciences, it may be seen as the sequence of efforts to maximize self-interest, through attempts to gain power, status, and influence.

The concept of career used in this work involves subjective and objective aspects. The subjective aspect deals with the course of life of the individual, referring to "the sequence of roles and status and positions experienced by the individual" (HUGHES, 1937, p. 404); in addition to a bureaucratic structure of employment or occupation, the individual will have a career. Thus, "a career is the dynamic perspective in which the individual sees his life as a whole and interprets the meaning of his various attributes, actions and the things that happen to him" (HUGHES, 1937, p. 409-410) by means of of the social roles played. However, Heslin (2005) points out that in the subjective context satisfaction with work and career can be criticized, taking into account that individuals might appreciate other aspects of the career. In the goal, the career is "clearly defined series of status and position" (HUGHES, 1937, p. 409), in which obligations, privileges, categories and status are clearly defined and accepted in the social context. However, institutions are ways that the collective behavior and collective action of the individual continue. In this context, career is a procedural combination of objective and subjective aspects.

As regards career models in industrial society, two are pointed out: the traditional model and the modern model (CHANLAT, 1995; TOLFO, 2002). The traditional model prevailed until the 1970s and favored stability, vertical linear progression, the sexual division 
of labor, from which women had no access to work and the possibility of ascension was only for the dominant groups. Evans (1996) points out in this model that the career was viewed as a ladder - each individual should find his ladder and seek higher levels of responsibility, status or pay.

The shift from the traditional model to the modern model has occurred with the entry of women into the labor market, demand for higher education, expatriation of workers, globalization of the economy, organizational changes and labor flexibility (CHANLAT, 1995). We are faced with a model in which women start their careers, attend to the presence of different social groups and less stable and less linear careers. It is in this context that Duarte and Silva (2013) emphasize the fact that in contemporary careers the instability and a nonlinear model is present.

Due to the analysis of the characteristics of contemporary careers, Schein (1990) proposes a career guidance tool. The career anchor is the individual's perception of their competencies, motivations and values, that is, it is self-knowledge about their professional preferences that allows for more conscious choices. From the individual point of view, the career consists of phases or stages that are perceived by the person and by society, although the time in each phase or stage varies according to the occupation of the individual. The label "career anchor" might be fundamental for a person, because it characterizes their motivation, values, career, company.

Other career models - the protean and without frontiers - and new perspectives on careers are highlighted in the following paragraphs.

The protean career arose from the works of Hall (1996), inspired by the Greek god Proteus, who according to mythology could change of form his will. Thus, the protean career is run by the person and not by the organization, and is adapted over time as change in the environment. The individual must develop self and his career, that is, self-knowledge in a process of continuous learning, adaptability and collaborative participation. Therefore, the source of development is change in work, in relationships with their connections, and in interaction with other people. The goal of the protean career is psychological success, the feeling of pride, personal fulfillment as family happiness and inner peace.

The career without frontiers was designated by Arthur (1994), who demonstrated that the individual can move his career beyond organizational boundaries, that is, careers are not limited to the borders of a single context, but to mobility around different organizations, jobs, occupations and regions in an unstable relationship. A career without frontiers provides a new status on modern careers in an environment of economic and organizational change. In this 
career, the individual must develop the roles of proactivity, creativity and the ability to direct one's own career (INKSON; GUNZ; GANESH; ROPER, 2012).

According to Deluca, Rocha-de-Souza and Chiesa (2016), the authors Adamson, Doherty and Viney (1998) bring new perspectives for career understanding from the point of view of interactionism when using Chicago school interactionism. These are three components - the situational context of career (social environment), relational (represented by the interactions of individuals with other meanings of the workplace) and chronological (the perspective of movement in time) - that are relevant to the contemporary notion of a work career. To speak of career within this context one must speak of the sequences of roles and experiences of individuals, especially in the social environment over time (HUGHES, 1937).

According to Abbott (1997), social relations happen in the daily interaction of individuals. Therefore, in order to understand social life, it is necessary to understand the context of social actors and their particularities of time and place. Thus, "social facts are localized" (ABBOTT, 1997, p. 1152), because the focus is on social and spatial relations, surrounded by other contextual facts in the process of interaction with social contexts. In this scenario of social interactions, Becker (2008) studies the outsider career from the perspective of interactionism and the deviance sociology.

Sociology (of deviation) views deviation as the adoption of extravagant and unconventional patterns of behavior within a given culture or community. According to Becker (2008), individuals or groups whose behavior is considered deviant in the context of that culture or community are labeled as outsiders. It is in the condition of outsiders that their own lifestyles are developed and according to rules, standards and conventions engendered in this deviant/outsider condition. Individuals or groups that present behaviors or develop activities considered deviant face problems because their behaviors and activities are not shared by other members of society (BECKER, 2008).

In the labeling theory, the outsider concept proposed by Becker $(2008$, p. 27) refers "to designating those people who are considered deviant by others, thus standing outside the circle of the 'normal' members of the group". Depending on the process of judgment, a social group identifies in another group a behavior considered outsider, that is, a behavior considered outside the normal standards for this group, thus the labeling process arises.

It is important to note that, according to Becker (2008), the deviant groups have a selfjustifying or ideological foundation, based on psychological and sociological justifications, perceived as valid by the deviant, but not by the legal system or by society. 


\section{OUTSIDER CAREER: THE LABELING THEORY}

In the Department of Sociology at the University of Chicago and Anglo-Saxon authors, in the 1920s, the sociology of deviance emerged in the nineteenth century, a discipline whose purpose was to conceptualize social problems as crimes, delinquency, alcoholism, vagabondage, madness, prostitution, suicide, philosophical and religious treatises. The University of Chicago, based on a pragmatic approach, based its research on the ideas and experiences of everyday life, that is, on the analysis of social groups and their relationships - symbolic interactionism (LIMA, 2001; MISKOLCI, 2005).

According to Lima (2001), the sociology of deviation is divided into two theoretical and philosophical currents: positivism and symbolic interactionism. The first is to analyze the three causes of deviation: functionalist, anomie and culturalism. The functionalist or structuralist approach refers to society in terms of the mechanisms of nature, that is, of biological life. Thus, society is a "body" in which the parts must relate to the whole. The anomie highlights the weakening of the cohesion of the social system and the end of collective solidarities; the deviation is considered a result of social conflicts over individual consciences, with the possibility of causing the end of collective actors. For culturalist theorists, society is partitioned according to the different class cultures, in this way, with norms, beliefs and values proper to each class; deviant behavior is situated in one of the regions of the social system, and in conflict with the other components of the same system. In short, this current - positivist - has as object of study the organization or social disorganization to understand and explain the causes of deviant behavior. Within a normative paradigm, "deviation is viewed more as a dysfunction of society than as a complex social problem involving the interactions between distinct social groups" (LIMA, 2001, p. 191).

The second, interactionism, breaks with the causal focus and is concerned with the actions, relationships and social interactions of individuals, and the construction of the phenomenon in society occurs through social interactions. These relations are dialectical, through a dynamic process of interaction between the parties. Therefore, "the specificity of the interactionist theory, particularly Becker's "Labeling Theory", lies in collective action and the emphasis on the social process through which one individual or group is considered deviant by others" (LIMA, 2001, p. 185). In relation to the labeling process, Herpin (1982) emphasizes that it is a form of social control from which the deviant act can be corrected, assuming two forms: preventing the individual with deviant behavior from repeating this 
behavior again and is addressed to the group as a punishment and reaffirmation of the constituted rules.

Becker extends the study of the deviation to the notion of career that was employed in the studies of the sociology of the professions, when dealing with three components situational, relational and chronological. Thus, work career is concerned with social environment, by the interactions of individuals with other meanings of the workplace and the perspective of the movement in time (HUGHES, 1937). Therefore,

The sociology of deviance developed by Becker is based on the conditions under which standards are instituted. In addition, Becker and his interactionist approach calls for the understanding of deviation as a constantly elaborating process in which the individual can or can not engage. The more he engages, the more he is implicated and the harder it becomes to renounce it. The parallel with the sociology of work arises in the adoption of the notion of "career": each type of deviation consists of a specific career, but the scheme of engagement is similar: first there is a primary act (which may remain secret and even be non- intentional), then the acquisition of a deviant identity and, finally, adhesion to a deviant group. Becker underlines the fundamental role of society in the definition of deviant careers. (MISKOLCI, 2005, p. 28).

Becker (2008) describes the main phases of the deviation. The first stage is about committing an inappropriate act, that is, the transgression of a set of social rules. The reason for performing this act may or may not be conscious, influenced by the subculture of the individual. This infraction happens because there is a will on the part of the individual to overcome the conventional social commitments, which influences the passage of the social actors to the second phase. The second is joining an organized deviant group. The individual perceives and accepts his deviation, attributing a sense of belonging to him and consequently solidifies his identity. The third stage is the discovery and social labeling of an actor as an outsider. Thus, the individual crystallizes his deviant behavior in the way society treats the individual and how he perceives himself in society and positions himself. In the fourth stage, the individual, when treated as deviant, will "suffer" the perception of social failure. In the last stage, the social actor remaining in the deviant career will enter into a deviant, organized and structured social group, sharing the same fate and problems of the deviant subculture.

The deviation is a behavior of the individual that is identified as unconventional to the standards established by society; thus, a specific identity is attributed to the individual. In this sense, the individual labeled as an outsider may or may not accept this judgment of society (HERPIN, 1982; CENTURIÃO, 2003; BECKER, 2008). The normal and the outsider are not 
people, but perspectives of society and the deviation is not part of the individual, but a situation that can lead to labeling (CENTURIÃO, 2003).

The deviation is thus a product of interaction, resulting from which the rules are formulated in a more or less explicit way, existing behaviors implied and implicit rules that allow variations in actions, being relative the stability of the rules. Therefore, in this conception, the deviant behavior can be considered an incorrect attitude that influences a preestablished system of demands and expectations, before which there is the recognition and the public accusation as deviant (HERPIN, 1982; VELHO, 1985; CENTURIÃO, 2003, BECKER, 2008).

The labeling theory "is not concerned with the act itself, but with the quality of being a deviant act. That is, to understand the process by which people define some actions as bad and the consequences that such a definition causes" (BECKER, 1977, p. 23). According to Herpin (1982, p. 83), "the act of deviance ceases to be a time when the individual transgresses the law, to be the complex process in the course of which the individual is designated as deviant." Therefore, the concern is not with the transgression of the act, but with the process of labeling successfully applied to an individual, or group of individuals by the other members of society (BECKER, 1977; HERPIN, 1982; MILKOLCI, 2005; BECKER, 2008).

The labeling theory opens up an approach in which behaviors labeled as deviant are not the focus of research, but rather the means by which certain social groups hold the power to label others as deviant (MISKOLCI, 2005). In this sense, different groups consider different deviant things. To exist the outsider, there must exist the "normal", and the opposite is true due to the process of judgment. Miskolci $(2005$, p. 27) points out that "it is necessary to take into account those who impose the standards or formulate the accusations by showing how such an individual or group comes to transgress that norm or was labeled as deviant."

In this sense, different groups consider as deviant different actions or behaviors. To exist the outsider must exist the "normal" and the opposite is true due to the process of judgment. The definition of the rule does not guarantee that it is imposed, because in the same social context there are the "normal" and the outsiders, who face the causes and effects of the process of labeling in function of the process of judgment (GOFFMAN, 2004; BECKER, 2008).

According to Becker (2008, p. 15), "all social groups make rules and try, at certain times and in some circumstances to impose them. Social rules define situations and types of behavior appropriate to them, specifying some actions as "right" and prohibiting others as 
"wrong". Therefore, when a rule is imposed and an individual does not behave as established by the group, the individual is considered an outsider. Thus, the process of making rules and identifying those who violate them occurs. Therefore, the deviation is not the quality of the act that the individual practices, but a definition by others of rules and sanctions to a "violator" (BECKER, 2008). According to Goffman (2004), a deviation refers to group of individuals who share values and social norms referring to a personal behavior and attributes of another group of individuals.

According to Becker (2008: 141), "if specific rules are applied in specific situations, they are applied to specific people, in specific circumstances, we must see who has taken care of the application and enforcement of the rule occurs. " Therefore, the support of others interested in the imposition of the rule should occur, that is, the labeling process has the interest and support of other groups. According to Hughes (1958), the rules classify people to define appropriate behaviors in certain social contexts and assign social roles to those involved.

According to Becker (2008, p. 22), the deviation is

[...] like the product of a transaction between a social group and an individual who, in the eyes of the group, transgressed a norm, being less interested in the personal and social characteristics of the deviants than by the process by which they are considered strangers to the group, as well as by their reactions to that judgment.

According to Becker (2008, p. 29), the labeling process implies a politically and economically legitimized relationship of power, "to the extent that one group tries to impose its norms on other groups in society, a second question is: which categories are in practice capable of compelling others to accept their norms, and what are the causes of the success of such an enterprise?"

For Becker (2008), there are four types of behaviors. "Appropriate" behavior is one in which the individual follows the rules that others perceive as such. A second type is "pure deviant" in which the individual disobeys the rule and is perceived as such. Another type of behavior is what the author calls "falsely accused," referring to the person who is seen by others as having done something wrong, but in fact did not. The "secret diversion" concerns the individual who commits an improper act (or violates the rules), but is not perceived. Furthermore, there should be the audience's decoding ability on the perception of the deviation (GOFFMAN, 2004). In the interactionist perspective, the violation of the norm 
does not result in a deviant career, but the society's reaction when recognizing an infraction (HERPIN, 1982). Table 1 shows the types of behavior reported.

Table 1 - Types of behavior

\begin{tabular}{|l|l|l|}
\hline \multirow{2}{*}{ Societal reactions } & \multicolumn{2}{|c|}{ Nature of behavior } \\
\cline { 2 - 3 } & Appropriate Behavior & Offensive behavior \\
\hline Perceived as deviant & Falsely accused & Pure deviant \\
\hline Not perceived as deviant & Appropriate & Secret deviant \\
\hline
\end{tabular}

Source: Becker (2008, p. 31).

A useful conception in the development of sequential models of various types of deviant behavior is the career. Based on occupational studies, the concept deals with a change of position to another within that system. In this way, it is mentioned that the model can be used to study deviant careers (BECKER, 2008). Therefore, "deviant behavior is in conflict with public order, which is, in short, an order that governs social interaction" (CENTURIÃO, 2003, p. 19). Thus, the deviant attitude can be understood as a failure, intentional or not in the implicit or explicit execution of the established rules, however, the normative rules of the deviant behavior varies from culture to culture, that is, the social context, the perspectives, and the interests of individuals in the process of judgment (CENTURIÃO, 2003).

\section{THE OUTSIDER CAREER IN THE INTERACTIONIST PERSPECTIVE}

The paradigm in social science refers to the meta-theoretical assumptions that ground the field of reference, the way to theorize the development of the respective theories. The paradigm aims to highlight what is common in the different perspectives, that is, what belongs to the work of a certain group of theorists, and what the group approaches in social theory from the limits defined by a common problematic (BURREL; MORGAN, 1979). Each paradigm is characterized by a set of schools with different approaches and perspectives, but which have in common fundamental assumptions about the nature of reality (MORGAN, 1980).

According to Burrell and Morgan (1979), social science can be understood in paradigms, each of which consists of: ontology, epistemology, human nature and methodology. Ontology refers to the very essence of the phenomenon under investigation. Associated with the ontological assumption is the epistemology that deals with the knowledge bases, that is, the possible forms of knowledge. Relating the ontological and 
epistemological assumptions, the set of assumptions referring to human nature arises, which is concerned with the relationship between man and the environment. The three assumptions have methodological implications, that is, their influence in the form of research and acquisition of knowledge of the social world.

Following Burrell and Morgan (1979) (among many others), social theory can be understood in four paradigms, the functionalist, the interpretative, the radical humanist, and the radical structuralist, anchored in different assumptions, such as ontological, theoretical, human and method. The four paradigms together provide an orientation for the thematic area to identify the similarities and differences between their theories, that is, a way of mapping the references they adopt.

Of these, it is important to focus on the interpretative paradigm, which aims to understand the social world at the level of subjective experience. In the view of the reality of interpretativism, the sociology of regulation emerges as implicit and not explicit, once this vision is oriented towards the understanding of the social world, that is, to the essence of everyday life (BURRELL; MORGAN, 1979). The interpretive social researcher tries to understand the social process through which multiple realities arise, sustain themselves, and change. Thus, social reality is not something established, but negotiated (MORGAN; SMIRCICH, 1980).

According to Morgan (1980), symbolic interactionism belongs to the interpretative paradigm, seeking to understand the social reality of the subjective and intersubjective experiences of individuals. Symbolic interactionism emerged as a reaction to the positivist model, emphasizing the construction of experiences, the choices of individuals, social relations and meanings as a product of social interaction (GUERRA, 2002). For Mendonça (2002), symbolic interactionism is a macrossociological school that has its assumptions in sociology and anthropology, and it is a theoretical perspective and a methodological orientation. According to Mendonça (2002), Carvalho, Borges and Rêgo (2010) and Haguette (2010), the precursors of symbolic interactionism were George Mead and Hebert Blumer and the contributions of the Chicago school.

According to Blumer (1986), the nature of symbolic interactionism has three basic premises: first, the action of human beings occurs from the meanings that are perceived in the social context the individual is inserted, the second comes from the interaction someone has with a partner, and third, meanings are modified by interpretative process of events that people face. 
Anchored in these premises, Carvalho, Borges and Rêgo (2010) emphasize that the symbolic interaction involves a scheme of human society that relates to the nature of human groups or society, social interaction, human action and interconnections between the lines of action. The individual and society preserve a social interaction and the subjective aspect of human behavior is relevant in the formation and maintenance of the social dynamics of the social self and the social group (GODOY, 1995).

According to Haguette (2010, p. 54), symbolic interactionism comprises "society as an entity composed of individuals and groups in interaction (with themselves and with others), based on the sharing of meanings in the form of understandings and common expectations ". Therefore, the process of social interaction is anchored in dynamic social action, changing according to the different contexts experienced by individuals and groups. In this way, in the interactive process of social life, rules are created, maintained and modified (HAGUETTE, 2010).

Interactionism comes from a theoretical perspective that enables individuals to interpret objects and other individuals in the process of social interaction, so that individual and world are not to be understood in isolation. Therefore, it is an appropriate approach for studying social relationships (CARVALHO; BORGES; RÊGO, 2010). For interactionism, every societal organization is supported by the senses, differences and actions of the individuals and groups that develop along the process of social interaction (HAGUETTE, 2010).

According to Herpin (1982), in the sociology of the Chicago School, interactionism is used for career study and deviance. In this way, it is intended to understand the deviation by the situations in which the designation of deviant may occur and not from the individuals, their behaviors and from the rules that have been transgressed. Therefore, the problem is to know "what characterizes the interactions in which the designation of deviants occurs". For interactionism there is an outsider process analysis (HERPIN, 1982, p. 89). "The central point of the interactionist approach of deviance is to make it clear that someone had to do the labeling" (BECKER, 1977, p. 34).

According to Xiberras (1993), Becker's labeling theory attentive to social action when considering norms, socialization, and deviation for the outsider concept "to designate what contains from strangeness both the look of the deviants to the normal ones, as the look from the normal to the deviants "(p.118). Becker (2008) does not worry about the transgression of the act itself, but with the process of labeling of the individual. Social interaction is plural 
when considering two groups: those who transgress rules and those who react to the act of transgression (GUERRA, 2002).

In the interactionist perspective, there are some questions that guide it regarding social actors who are presented as socially deviant: What are the circumstances through which an individual is labeled as deviant? How do social actors play the role of deviants? What is the social value attributed to the elements of the deviation? How does a social actor act in front of a label? How do deviants assimilate and reproduce their social role? What are the changes produced in the group of deviants to which they belong? (GUERRA, 2002).

In this context, the ontology, epistemology, human nature and the method of symbolic interactionism for the study of the career will be presented.

The ontology of interactionism is based on what is called symbolic discourse. The social world is based on a pattern of meanings and symbolic relations through the processes of human interaction and action in a social environment of interpretations (MORGAN; SMIRCICH, 1980). In this sense, the career in the social world has a pattern of meanings and symbolic relations in human interaction and action in a social environment of interpretations.

The epistemology of interactionism is based on the understanding of the patterns of symbolic discourse. In this way, the understanding of the processes of the individual's interaction with the social world occurs. Reality is not based on a system of rules, but on a system of meaningful action that becomes to an observer as a set of rules. The idea of a social world of relations, deterministic, and it is defended the knowledge, the understanding and the explanation on the social relations considering how the social order is developed and what meanings the individuals attribute to it (MORGAN; SMIRCICH, 1980).

The human nature of interactionism refers to the individual who becomes a social actor when he interprets his environment and directs his actions in ways that are meaningful to him. In this process, individuals use language, labels, routines to manage impressions and other specific models of actions contributing to promote a reality (MORGAN; SMIRCICH, 1980). The individual becomes alive in the world, interpreting and promoting a relationship in his daily life in the empirical reality of human experience in the way humans see reality (MORGAN; SMIRCICH, 1980; GODOY, 1995). So, what are the interpretations that individuals as social actors attribute to the exercise of a career considered outsider?

The method of research of interactionism is the symbolic analysis. Meaning is an essential item in the understanding of human behavior, social interactions and processes (CARVALHO; BORGES; BORGES, 2010). Given the characteristics presented on symbolic interactionism, the qualitative approach becomes coherent in theoretical and methodological 
terms (GODOY, 1995). According to Godoy (1995), qualitative research does not concern to enumerate events or to use statistical elements, but to obtain data about people, places and interactive processes in order to understand the phenomena that manifest themselves on the perspective of the individual and their social interaction. The qualitative approach aims to obtain descriptive data about people, environments, certain phenomena, trying to understand the participants in their social relation and their natural environment. Qualitative researchers are inductive in data analysis, they do not start from established hypotheses, but from broad questions that become more specific in the way of research.

In this way, Godoy (1995) and Haguette (2010) present qualitative methodologies for the development of research within the perspective of interactionism, namely: participant observation, life history, interview, and oral history.

\section{INTERACTION OF KNOWLEDGE AREAS}

From what has been discussed in the previous sections, a synthesis of the approximation of knowledge areas is presented. In American sociology, specifically in the Chicago School, lies the sociology of deviance. The sociology of deviance has two aspects, the functionalist and the symbolic interactionism. Interactionism can be considered a theoretical and methodological perspective. In theoretical terms, it seeks to understand the social interaction of individuals and the labeling process, within which the theory of Becker's labeling (2008) is evidenced. Regarding the methodology, this is a qualitative approach, with methods and data collection techniques such as observation, interview with semi-structured script, oral history and life history (HERPIN, 1982, GODOY 1995, LIMA, 2001, CENTURIÃO, 2003, HAGUETTE, 2010).

In management, early career studies dealt with the traditional career model, but with the changes that occurred in the organizational context began to worry about the modern career model (CHANLAT, 1995). On the types of career, we can mention the anchor (SCHEIN, 1990), protean (HALL, 1996) and without frontier (ARTHUR, 1994). Already Adamson, Doherty and Viney (1998) and Mendonça (2002) propose the understanding of the career from the perspective of interactionism.

Figure 1 represents the two areas of knowledge and their dismemberments, demonstrating their approximation. 


\section{Figure 1 - Approximations of themes}

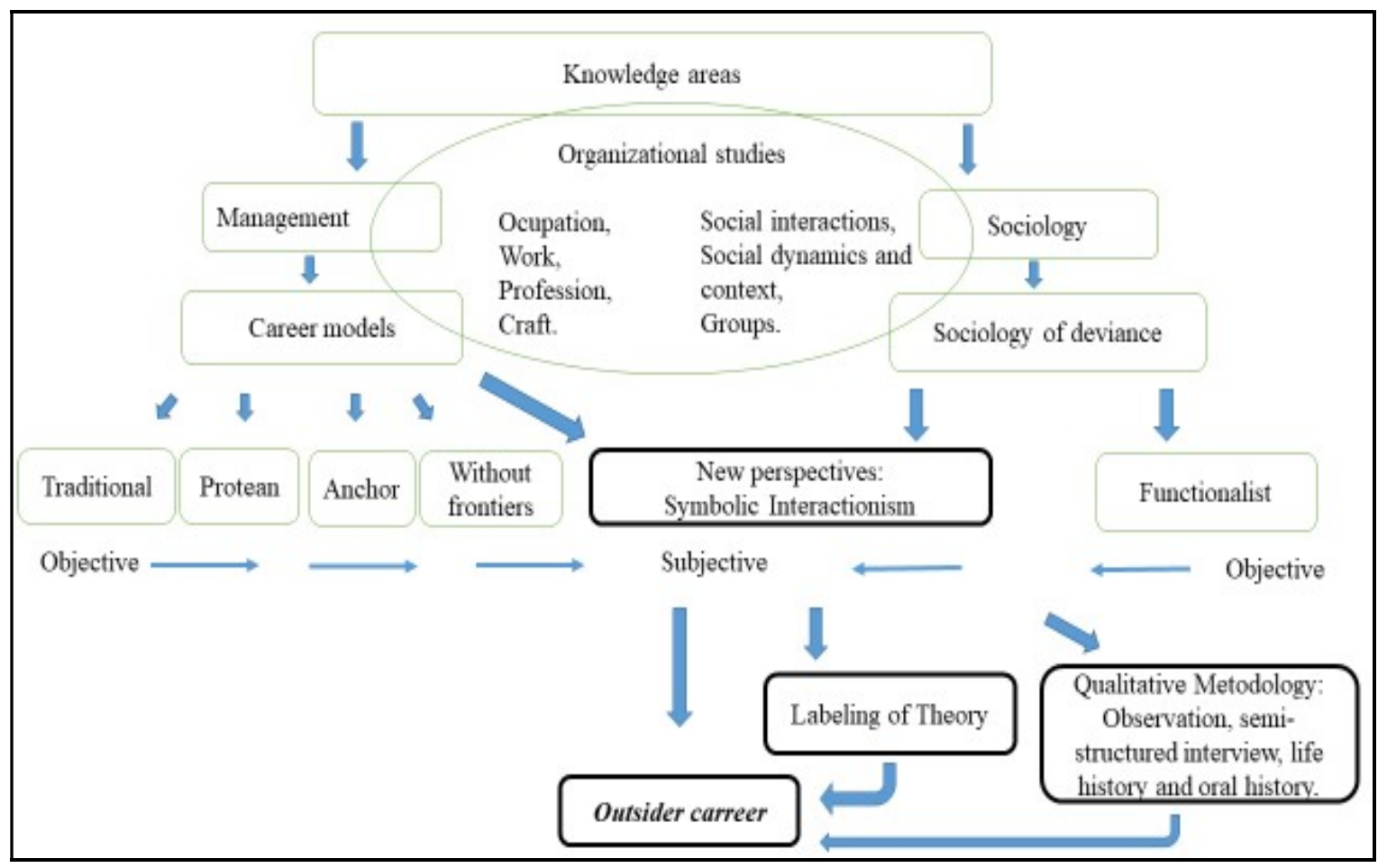

Source: elaborated by the authors.

It is proposed to move from the objective perspective to the subjective perspective of the career comprehension both in the area of administration and sociology, in order to allow an interdisciplinary approach to the study of the career. Thus, the aim is to fill a gap in the use of the interdisciplinary approach and make possible new perspectives for career study (MENDONÇA, 2002; KHAPOVA; ARTHUR, 2011). In this sense, it is possible to analyze the career of the outsider musician, considering their relationships, social interactions, developed social roles and the subjective aspect of the individuals through the qualitative methodology with approach of the two areas of knowledge.

\section{FINAL CONSIDERATIONS}

The objective of this work was to present a theoretical and methodological discussion for the study of career in the perspective of symbolic interactionism. And therefore, to stimulate researchers to appropriate the perspective of symbolic interactionism in the conception of the outsider career and its process of labeling in the social context of the actors involved in their interactions. 
The literature presents the gap for the interdisciplinary approach of the study on careers. However, when conducting the study of careers in the context of administration, with a theory and methodology of sociology, this gap can be filled, providing an expanded view of the phenomenon under analysis.

The study of career in the interactionist perspective allows to broaden the view about the object of study, since it seeks to understand the thematic about the process of social interaction of all the social actors involved - individual, family, society, organizations with a view focused on career subjectivity (HUGHES, 1937; BECKER, 2008). In order to understand the social environment, the interactions of individuals and their movement over time, that is, a more comprehensive perspective. There is, in the concept of career, a clear intentionality of relativism, of incessant construction and reconstruction. This dynamism is more relevant and allows us to place careers in the historical course of time, a fundamental perspective for interpreting the contemporary mobilities of professions and also experiential precariousness.

The use of labeling theory for career study seeks to understand the psychological, social and professional implications of exercising a career considered outsider by society, analyzing the social relations of individuals in the transgression and accusation of an act considered outsider by the other members of the society. Describing the political process of interactions and power relations in the confrontation between the group(s) that label and apply the label and the group(s) that are labeled. As an example, the careers that do not accept morally - sex workers, itinerant careers - the circus artist, the musician. Identify the group(s) that make the rules and in what contexts they apply the label, how the rules are maintained and modified. The entities of the cbo, the record companies, the professional councils and other organs. Thus, Barros et al., (2016) proposes the following careers that can be studied in this perspective: visual artists, craftsmen, actors, musicians, traditional and popular dancers, circus artists, models, athletes, astrologers and numerologists, esotericists, sex workers and other careers that frame in the outsider career concept. In addition, there is still the possibility to think of other forms of work as a career: the career of mother, father, domestic, housewife, that involve work situations, dedication, expertise, responsibility, but they are not always considered as such.

The perspective of symbolic interactionism has not been exhausted in this work, because there are different theoretical and methodological possibilities (MENDONÇA, 2002). Thus, it was not an objective to present all the possibilities of symbolic interactionism, but new opportunities for study. Despite the limitations presented, it is hoped that the 
perspective of symbolic interactionism may contribute to new research in theoretical and methodological terms.

${ }^{1}$ The first version of labeling theory was published in 1963. However, the version that has been used in this work is the latest published in Brazil, in 2008.

${ }^{2}$ In previous works in Brazil it was common to perform the translation of outsiders by "marginal and deviant", pointing out that "deviant" meant, in this context, someone who is outside, beyond the margins of a certain boundary or social boundary. In this work the two terms, deviant and outsider will be used, since the term outsider became consecrated in the Social Sciences.

\section{Acknowledgements}

The authors thank IF SUDESTE MG for the financial support.

\section{REFERENCES}

ABBOTT, A. Of time and space: The contemporary relevance of the Chicago School. Social Forces, v. 75, n. 4, p. 1149-1182, 1997.

ADAMSON, S. J.; DOHERTY, N; VINEY, C. The meanings of career revisited: Implications for theory and practice. British Journal of Management, v. 9, n. 4, p. 251-259, 1998.

ARTHUR, Michael B. Examining contemporary careers: A call for interdisciplinary inquiry.

Human Relations, v. 61, n. 2, p. 163-186, 2008.

ARTHUR, M. B. The boundaryless career: A new perspective for organizational inquiry. Journal of Organizational Behavior, v. 15, n. 4, p. 295-306, 1994.

BARROS, L. E. V. et al. Carreiras outsiders: uma análise a partir da classificação brasileira de ocupação (CBO) Anais... XIX SEMEAD, 2016.

BECKER, H. S. Outsiders: estudos de sociologia do desvio. Rio de Janeiro: Zahar, 2008.

BECKER, H. S. Uma teoria de ação coletiva. Rio de Janeiro: Zahar, 1977.

BENDASSOLLI, P. F. Recomposição da relação sujeito-trabalho nos modelos emergentes de carreira. RAE-Revista de Administração de Empresas, v. 49, n. 4, p. 387-400, 2009. BLUMER, H. Symbolic interactionism: perspective and method. California: Univ. of California Press, 1986. 
BURRELL, G.; Morgan, G. Sociological paradigms and organizational analysis: elements of the sociology of corporate life. London: Routledge, 1979.

CARVALHO, T. A. T. A escolha e o comprometimento com a profissão/carreira: um estudo entre psicólogos. Dissertação (Mestrado em Psicologia) - Faculdade de Filosofia e Ciências Humanas. Salvador: Departamento de Psicologia da Universidade Federal da Bahia, 2007.

CARVAlHO, V. D. de; BORGES, Livia de Oliveira; RÊGO, Denise Pereira do. Interacionismo simbólico: origens, pressupostos e contribuições aos estudos em Psicologia Social. Psicologia: Ciência e Profissão, v. 30, n. 1, p. 146-161, 2010.

CENTURIÃO, L. R. M. Identidade e desvio social. Curitiba: Juruá, 2003.

CHANLAT, J.-F. Quais carreiras e para qual sociedade? Revista de Administração de Empresas, v. 35, n. 6, p. 67-75, 1995.

CLOSS, L.; ROCHA-DE-OLIVEIRA, S. História de vida e trajetórias profissionais: estudo com executivos brasileiros. RAC-Revista de Administração Contemporânea, v. 19, n. 4, p. 525-543, 2015.

DELUCA, G.; ROCHA-DE-OLIVEIRA, S.; CHIESA, C. D. Projeto e metamorfose: contribuições de Gilberto Velho para os estudos sobre carreiras. RAC-Revista de Administração Contemporânea, v. 20, n. 4, p. 458-476, 2016.

DUARTE, M; SILVA, A L. A experimentação do risco na carreira criativa: o caso de mestres da cultura do artesanato cearense. Revista Eletrônica de Ciência Administrativa, v. 12, n. 2, p. 156-172, 2013.

SCOTSON, J. L.; ELIAS, N. Os estabelecidos e os outsiders: sociologia das relações de poder a partir de uma pequena comunidade. Rio de Janeiro: Jorge Zahar, 2000.

EVANS, P. Carreira, sucesso e qualidade de vida. Revista de Administração de empresas, v. 36, n. 3, p. 14-22, 1996.

GODOY, Arlida Schmidt. Introdução à pesquisa qualitativa e suas possibilidades. Revista de Administração de Empresas, v. 35, n. 2, p. 57-63, 1995.

GOFFMAN, E. Estigma: notas sobre a manipulação da identidade deteriorada. Rio de Janeiro: LTC, 2004.

HAGUETTE, T. M. F. Metodologias qualitativas na sociologia. Petrópolis: Vozes, 2010. HALL, D. T. Protean careers of the 21 st century. The Academy of Management Executive, v. 10, n. 4, p. 8-16, 1996. 
HERPIN, N. A sociologia americana: escolas, problemáticas e práticas. Porto: Edições Afrontamento, 1982.

HESLIN, P. A. Conceptualizing and evaluating career success. Journal of Organizational Behavior, v. 26, n. 2, p. 113-136, 2005.

HUGHES, E. C. Institutional office and the person. American Journal of Sociology, v. 43, n. 3, p. 404-413, 1937.

INKSON, K., GUNZ, H.; GANESH, S.; ROPER, J. Boundaryless careers: bringing back boundaries. Organization Studies, v. 33, n. 3, p. 323-340, 2012.

KHAPOVA, S. N.; ARTHUR, M.B. Interdisciplinary approaches to contemporary career studies. Human Relations, v. 64, n. 1, p. 3-17, 2011.

LIMA, R. C. P. Sociologia do desvio e interacionismo. Tempo Social, v. 13, n. 1, p. 185-201, 2001 .

MENDONÇA, J. R. C. Interacionismo simbólico: uma sugestão metodológica para a pesquisa em administração. Revista Eletrônica de Administração, v. 8, n. 2, 2001. MISKOLCI, R. Do desvio às diferenças. Teoria \& Pesquisa, v. 47, p. 9-41, 2005. MORGAN, G. Paradigms, metaphors, and puzzle solving in organization theory. Administrative Science Quarterly, v. 25, n.4, p. 605-622, 1980.

MORGAN, G.; SMIRCICH, L. The case for qualitative research. Academy of management review, v. 5, n. 4, p. 491-500, 1980.

OLIVEIRA, L. B. Carreiras "Exóticas": o que Administradores Podem Aprender com as Vivências de Artistas, Atletas e Outros Profissionais. Revista de Carreiras e Pessoas (ReCaPe). v. 1, n. 2, p. 1-28, 2011.

SCHEIN, E. H. Career Anchors: Discovering Your Real Values Jossey-Bass. San Francisco: California, 1990

GUERRA, Paula. Cenários de Insegurança: contributos do interaccionismo simbólico para uma análise sociológica da construção mediática do desvio, 2002. Disponível em: https://repositorio-aberto.up.pt/handle/10216/53668. Acesso em: 22 jan. 2018.

TOLFO, S. da R. A carreira profissional e seus movimentos: revendo conceitos e formas de gestão em tempos de mudanças. Revista Psicologia Organizações e Trabalho, v. 2, n. 2, p. 39-63, 2002.

VELHO, G. Becker, Goffman e a antropologia no Brasil. Ilha Revista de Antropologia, v. 4, n. 1, p. 5-16, 2002.

VELHO, G. O estudo do comportamento desviante: a contribuição da antropologia social. Desvio e divergência: uma crítica da patologia social, v. 6, p. 11-28, 1985. 
VIEIRA, A; LIMA, C. H.; PEREIRA, G. B. Papéis sociais e expectativas. In: VIEIRA, A.; GOULART, Í. B. (Coords). Identidade e subjetividade na gestão de pessoas. Curitiba: Juruá, 2007, p. 27-54.

XIBERRAS, M. As teorias da exclusão: para uma construção do imaginário do desvio. Lisboa: Instituto Piaget, 1993. 